\title{
Late Messinian palynoflora from Central Anatolian Plateau (Çankırı Basin)
}

\author{
Müge Atalar', Marianna Kováčová ${ }^{1}$, Mine Sezgül Kayseri Ozer², Torsten Utescher ${ }^{3}$ \\ ${ }^{1}$ Comenius, University in Bratislava, Faculty of Natural Sciences, Department of Geology and Palaeontology; \\ Ilkovičova 6, Mlynská dolina, 84215 Bratislava, Slovakia; e-mail: atalar@fns.uniba.sk \\ ${ }^{2}$ Dokuz Eylul University, The Institute of Marine Sciences and Technology \\ ${ }^{3}$ Universitat Bonn; Nussallee 8, Raum 305 Buisy - NR: 3.005
}

(C) 2016 Authors. This is an open access publication, which can be used, distributed and reproduced in any medium according to the Creative Commons CC-BY 4.0 License requiring that the original work has been properly cited.

Within the framework of the Marie Curie FP7PEOPLE-2013-ITN program, the ALErT project targets on tectonic and climatic boundary conditions in the regions along the densely populated and the associated with natural hazards part of the Central Anatolian Plateau. The wide Central Anatolian Plateau (CAP) extends between the Aegean extensional and Bitlis /Zagros compressional zones. The Çankırı Basin was opened in central Anatolia during Late Cretaceous between the Kırşehir block in the south and Sakarya continents in the north. During the Neo-Tethys closure, the basin became a large intermontane basin covered with continental sedimentary environments (Kazanc1 et al. 1999). During the Late Miocene, there were different types of lacustrine environments between the northern and southern parts of this basin. Age evidence of the Çankırı Basin deposits has been obtained from the European mammalian faunal zones, because the $\mathrm{Sr}$ analysis results have not be significant to interpreted age (Mazzini 2015).

To figure out the paleoenvironmental and palaeoclimate changes in Çankırı Basin biotic (palynology) and abiotic proxy data (geochemical, $\delta 18 \mathrm{O}-\delta 13 \mathrm{C}$ isotopes analyses and $\mathrm{CaCO}_{3}$ ) were analysed. Fifteen samples from Hancili Formation, Tuglu Suleymanli crossing border, Bozkır Formation and Değim Formation were collected from claystone, dark silty clay, gypsum and breccia with silty gypsum layers in the Çankırı Basin. The samples were treated by standard palynological procedures described by Cour (1974). All pollen samples, residues, and slides are stored in Comenius University in Bratislava, Slovakia.

Each sample collected in the Çankırı Basin contains 150 pollen grains excluding Pinus. Pollen identification was performed under a Zeiss light microscope, and under a Quanta FEG250 Scanning electron microscope (SEM) used for high resolution imaging of pollen grains in Institute of Electrical Engineering Slovak Academy of Sciences. The pollen diagram was prepared with Tilia*Graph (2.0) (http://www.chrono.qub.ac.uk/datah/ tilia.html).

According to Mosbrugger \& Utescher (1997), coexistence approach derived quantative paleoclimate parameters. To explain the ecological characteristic, we used version of the Past 3.x - the Past of the Future free software scientific statistical data analysis program (http://folk.uio. no/ohammer/past/). Head map was prepared using program for four formations. The uplift during the Late Messinian in Çankırı Basin has been confirmed by palynological data and head map evaluation. We applied Xact 8 for the graphic presentation to show vegetation composition. We developed Steppe-Forest Index using a ratio of appropriate species of pollen (Traverse 1978), that serve as a climatic indicator (warm to cold), while interpreting aridity we follow Cour \& Duzer (1978). As a consequence, the Poaceae/total Asteraceae ratio in a pollen diagram can be used as a climate index to find out dry to wet zones 
lines (Popescu 2006). It was calculated based on palynological results (using cluster analysis) to show that sections have four climate cycles with three dry periods. Based on those calculations, we confirmed long term cooling trend during the Late Messinian to the Plio-Pleistocene in Çankırı Basin. Most pollen spectra are mainly presented by Asteraceae, Chenopodiaceae, and Poaceae and by trees of Pinus, Cathaya, and Fagus. The group of herbs is important in the pollen spectra and mainly consists of Poaceae, Chenopodiaceae and Asteraceae, which document open grassland type of vegetation with warm - temperate climate.

\section{REFERENCES}

Cour P., 1974. Nouvelle technique de détection des fluxes et rétombées polliniques: étude de la sédimentation des pollens et des spores â la surface du sol. Pollen et Spores, $16,1,103-141$.

Cour P. \& Duzer D., 1978. La signification climatique, édaphique et sédimentologique des rapports entre taxons en analyse pollinique. Annual Mines Belg. 7-8, $155-164$.

Kazanc1 N. \& Varol B., 1999. Development of a mass flow-dominated fan-delta complex and associated carbonate reefs within a transgressive Paleocene succession, Central Anatolia, Turkey. Sedimentary Geology, 68, 261-278.

Mazzini I., Gliozzi E., Cosentino D., Kováčová M., Atalar M., Castorina F.\& Mastro L., 2015. Ostracoda from a late Messinian sabkha environment in the central Anatolia Plateau (Çankiri Basin, Turkey). [in:] $8^{\text {th }}$ European Ostracode Meeting, Abstracts, Tartu, Estonia 21-30 July 2015, University of Tartu, Estonia, 8.

Mosbrugger V. \& Utescher T., 1997. The coexistence approach-a method for quantitative reconstructions of Tertiary terrestrial paleoclimate data using the plant fossils. Palaeogeography, Palaeoclimatology, Palaeoecology, 134, 61-86.

Popescu M.S., 2006. Late Miocene and early Pliocene environments in the southwestern Black Sea region from high-resolution palynology of DSDP Site 380A (Leg 42B). Palaeogeography, Palaeoclimatology, Palaeoecology, 238, 64-77.

Traverse A., 1978. Palynological analysis of DSDP Leg 42B (1975) cores from Black Sea: Initial Reports of the Deep Sea Drilling Project. U.S. Government Printing Office, Washington D.C., 42B, 93-1015. 